\title{
Five-domed Churches of the 'Octagon-on-cube' Type: On the Question of Combination of Traditional and Innovative Forms in the Russian Church Architecture of the Eighteenth and Nineteenth Centuries
}

\author{
Natalia Merzlyutina ${ }^{1, *}$ \\ ${ }^{1}$ Scientific Research Institute of Theory and History of Architecture and Urban Planning (NIITIAG), Branch of \\ the Federal State Budget Institution "Central Scientific-Research and Project Institute of the Construction \\ Ministry of the Construction Ministry of Russia", Moscow, Russia \\ *Corresponding author. Email: merzlutina@mail.ru
}

\begin{abstract}
The article is centered at the important problem of the combination of traditional and innovative spatial compositions in Russian architecture under the reign of Tsar Peter the Great and their further development. The composition 'octagon-on-cube' appeared in the stone church architecture of Moscow at the end of the 17th century and was enrooted in the assortment of architectural forms. As early as in the beginning of the 18th century, it was connected with the traditional five-domed composition. As a result, a new version of the type 'octagon-on-cube' - five-headed 'octagon-on-cube' - was shaped. The new composition was kept for a long period of time - in the 18th and in the 19th centuries as well - becoming an integral part of various stylistic changes. This phenomenon demonstrates the exceptional importance of preserving the local tradition in the Russian sacred architecture of the 18th and 19th centuries.
\end{abstract}

Keywords: Russian five-domed churches, The octagon-on-cube type, Sacred architecture.

\section{INTRODUCTION}

A significant number of innovative typologies appeared in the Russian church architecture at the turn of the seventeenth - eighteenth centuries; they were developed in the further history of the sacred construction of Russia during the eighteenth and even in the nineteenth centuries. Among the new volumetric-spatial solutions, a special place was taken by churches with the composition of the main volume, which can be described as the octagon on a cube (the octagon-on-cube type). That type could be used in a joint structure with a centric plan with exedrae, a three-partite plan, or with the more traditional 'nave' plan, when the main church, its

*This study is based on the research, supported by the Program of Fundamental Research of the Russian Academy of Architecture and Construction Sciences and of the Ministry of Construction, Housing and Utilities of the Russian Federation 2021 . refectory and a bell tower were set on one axis. The early monuments of a new stylistic trend that appeared in Moscow architecture at the late seventeenth century later received the name of the so called 'Naryshkinsky style' (after the family name of the customers of many manor churches, Boyars the Naryshkins); the main volume of such composition of 'octagon-on-cube' were crowned with a single head with a cupola. An example is the Church of the Nativity of Theotokos in the Rozhdestvensky Pogost (1685-1686, commissioned by Prince A.P. Prozorovsky) [1]. For the first time among the churches of the 'Naryshkinsky style' with the central volume built as 'octagon-on-cube', the five-domed head, traditional for Russian medieval architecture, appears in the Assumption Church on Pokrovka (1696-1699, the customer, Merchant I.M. Sverchkov, the building was destroyed); it was set on the cube around the 
octagon, and the church had the three-partite volumetric-spatial composition. ("Figure 1")

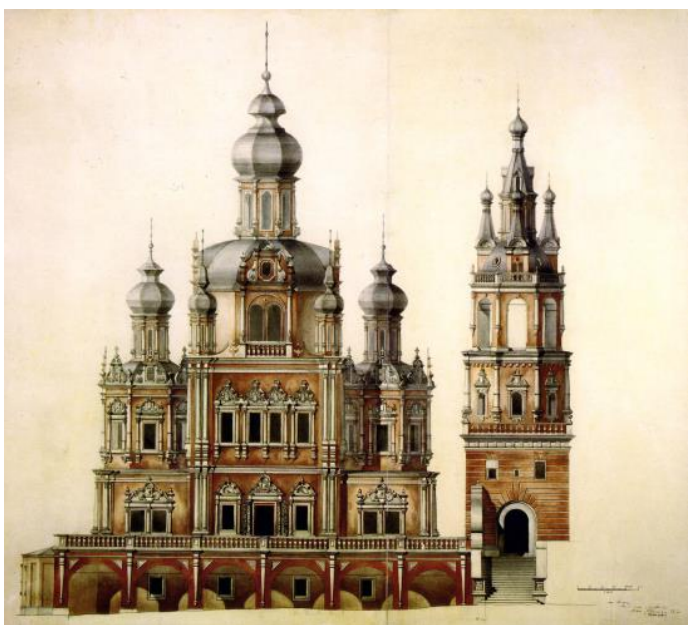

Figure 1 The Assumption Church on Pokrovka. 1696-1699. Measured drawing made before the deconstruction. 1937.

a The drawing is published on the site: https://hranitel.club/890-uspenskaya-
cerkov.

In the Russian church architecture of the late seventeenth century, among the innovative solutions that played a certain role in the formation of the typology in question, the five-domed composition oriented to the cardinal points also appeared. That variant of positioning the heads was associated with Ukrainian architecture and was called the 'Ukrainian five-domed' one. In some churches, the five-domed volume was set on the cube, and the side heads were raised on additional pedestals and formed a spatial cross around the two-tiered octagon of the central dome. The Moscow church of St. Paraskeva Pyatnitsa in Okhotny Ryad had such a composition (1686-1687, customer Prince V.V. Golitsyn, was destroyed) [3]. The Church of the Nativity of Theotokos (Stroganov) in Nizhny Novgorod (late seventeenth - early eighteenth centuries, customer G.D. Stroganov) belongs to the same version. [4] ("Figure 2")

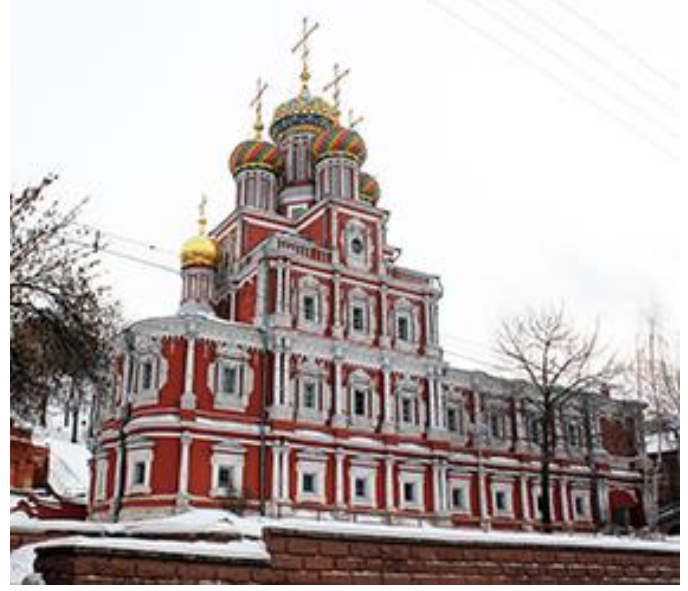

Figure 2 The Church of the Nativity of Theotokos (Stroganov) Church in Nizhny Novgorod, late seventeenth - early eighteenth centuries. Author's photo. 2012.

Of course, the new version of the church typology 'octagon-on-cube' crowned with five domes was associated with the desire of customers and craftsmen to create rather high church buildings and, at the same time, to preserve the well-known and easily recognizable five-domed head. The origin of this composition can be found as early as in the architecture of the period known as the 'ornamented style', in churches crowned with five domes set on a pyramid of 'kokoshniks' (a keel-like exterior decorative element). An early example exists in the Moscow Holy Trinity Church in Nikitniki (1631-1634, customer Merchant G.L. Nikitnikov). Similar traditional churches were erected also in the late seventeenth century, already in the 'Naryshkinsky style'; moreover, in some monuments, the second tier of 'kokoshniks' was transformed into a small octahedral decorative pedestal with beveled corners - a forerunner of the future large octagon. An example is the Moscow church of St. Sergius of Radonezh in Bolshaya Dmitrovka (1609-1700; was destroyed) [5].

\section{ON THE WAY TO CREATING A NEW COMPOSITION: FIRST EXAMPLES}

The masters' search for a way of combining of the composition of 'octagon-on-cube' with the fivedomed head was obvious in the bell towers construction in the late seventeenth century. An example is the bell tower of the abovementioned Assumption Church on Pokrovka, which was built as a composition of two octagons on the cube, crowned with a miniature tent-roofed five-domed 
head oriented at the cardinal points. Another example is the bell tower of the refectory of the Ascention Church of the Vyazhishchensky Monastery by Veliky Novgorod (1694-1698), which was built as one octagonal tier for bells set in the cube and crowned with five domes [6].

An important monument reflecting experiments of Russian architects in their search for the fivedomed church with the central composition of 'octagon-on-cube' is the nine-domed Church of the Mandylion with hospital chambers in the Tolgsky Monastery of the Entry of the Most Holy Theotokos into the temple, by Yaroslavl (about 1700) [7]. There is a central two-tiered head surrounded with eight domes - set diagonally and on the cardinal points - on the octagon of the church. ("Figure 3")

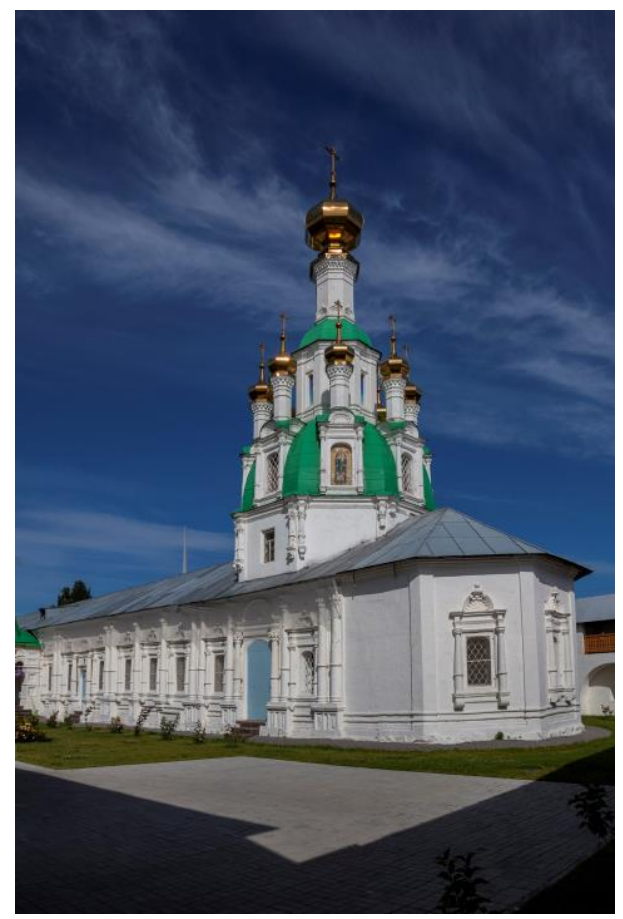

Figure 3 The Church of the Mandylion with hospital chambers in the Tolgsky Monastery. About 1700. Photo by A.V. Slezkin. 2016.

The Holy Trinity Cathedral in Verkhoturye (1703-1709), erected by Solikamsk masters under the supervision of the Moscow 'artel' (team) headed by T.M. Gusev, was the first monument where the five-domed head was combined with the type of 'octagon-on-cube'. It was also the first church of the 'octagon-on-cube' type on the vast territory of the Asian part of Russia, stretching beyond the Urals. The church was built as a 'nave', its five domes were oriented to the cardinal points, and the side domes were set on additional pedestals. Such composition resembles the volumetric-spatial structure of the crowning part of the Moscow church of St Paraskeva Pyatnitsa and the Stroganov Church in Nizhny Novgorod. But in this monument, for the first time, all five domes are set on the octagon; so, we can fix the shaping moment of a new version of the typology of 'octagon-oncube', which was further developed in the churches of two centuries [8]. ("Figure 4")

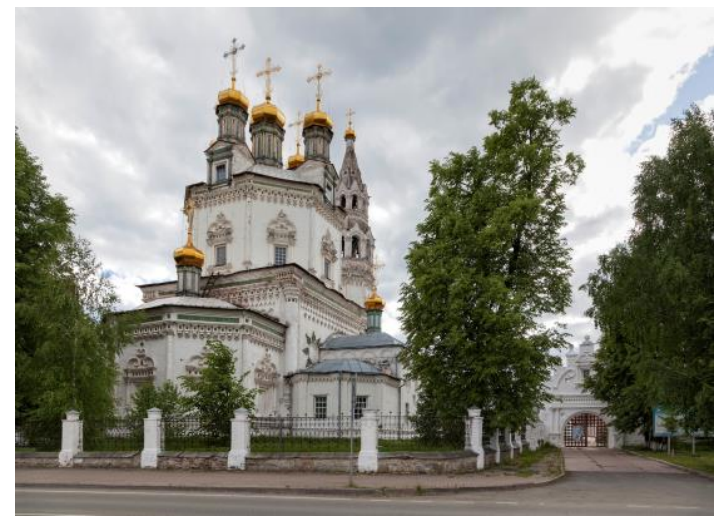

Figure 4 The Holy Trinity Cathedral in Verkhoturye. 1703-1709. Photo by A.V. Slezkin. 2019.

\section{FIVE-DOMED CHURCHES OF THE OCTAGON-ON-CUBE TYPE IN THE RUSSIAN CHURCH ARCHITECTURE OF THE EIGHTEENTH AND NINETEENTH CENTURIES}

Experiments on mastering the new volumetricspatial compositions in the church architecture at the epoch of Peter the Great lead to the formation of the new composition - 'five-domed octagon-oncube', that was wide-spread in the eighteenth nineteenth centuries. It is noteworthy, that the five domes of such churches were oriented usually 'in the Moscow way' (diagonally), not 'in the Ukrainian' one (at the cardinal points), and the façades could be decorated with archaic 'Naryshkinsky style', sometimes, with elements of the earlier, 'ornamental style'; basically, they were decorated in the style of Baroque or Classicism.

The study of the crowning parts of those monuments is complicated, because many churches have been destroyed or insufficiently studied, and we cannot precisely say, how many domes they had initially. The original five domes could be replaced by a single dome, or, conversely, four more domes could be added to only initial one during some later 
reconstruction. Such transformations could be traced back in the quite well-studied monuments of Siberia of the eighteenth century. The one-domed now Epiphany Cathedral in Irkutsk (1718-1746) was initially crowned with five domes; and the Epiphany Cathedral in Yeniseisk (1709-1712; head of the 'artel' F.M. Chaika), on the contrary, was originally one-domed, and four other domes were added after 1778 [9].

Understanding of the variant of typology, that is the subject of our research, is also complicated with the fact of irregular studying of the provincial architecture of Russia; as a result, we do have not a complete picture of development of Russian church architecture of the Modern time. The examples of five-domed churches of the 'octagon-on-cube' type given below relate mainly to the region of the Upper Volga (Tver, Yaroslavl, Kostroma, and partly Nizhny Novgorod), as well as a number of central regions, such as Smolensk and Ivanovo, which partially included the lands of Kostroma, Vladimir, and Nizhny Novgorod.

The Annunciation Church of Nerekhta, built in the first quarter of the eighteenth century (its fivedomed structure has not survived), can serve as an early example of the connection of five domes and 'octagon-on-cube' [10]. The variant of typology we are interested in has become quite widespread in the Kostroma and Yaroslavl Regions. It included, in particular, the Church of the Nativity of Christ on Debra in Kostroma (1734; not preserved). The church was constructed as a 'nave' and decorated with a simplified variant of the 'Naryshkinsky' ornamentation [11]. Among the monuments of the Yaroslavl Region, which have the volumetricspatial composition 'five-domed octagon-on-cube', we should mention the Church of St Boris and Gleb in the village of Starovo of the Uglich District (1753), made with elements of Baroque (round windows of the second tier and double pilasters of the cube), and the Church of the Nativity of Theotokos in the village of Pechelki of the Nekrasovsky District (1765). The Church of the Annunciation in Pyatnitsa-Vocha of the Soligalichsky District of the Kostroma Region (about 1772) has a developed variant of Baroque decoration [12]. The Church of the Resurrection of Christ in Yakshino in the same area (1795) was built in transitional forms from Baroque to Classicism [13].

There are church buildings of the similar type on the territory of the Smolensk Region, as well. An example of the first half of the eighteenth century in the belated 'Naryshkinsky style' is the Church of the Kazan Icon of Theotokos in Gzhatsk (now Gagarin; 1734-1737). The high building is shaped in a double octagon set on a two-tiered cube and crowned with five domes oriented in the 'Moscow style' [14]. The monuments in question on the territory of the Smolensk Region were demolished: the Annunciation Church in Vyazma (1715), and the Ascension Cathedral in Sychevka (1759-1775) [15].

Often the architecture of one monument which is a composition of 'five-domed octagon-on-cube', we can observe a bizarre combination of different styles. For instance, a combination of the Old Russian 'ornamentation' and Baroque elements of decoration could be found in the Church of the Transfiguration of Our Savior in the village of Rogozha, Ostashkovsky District of the Tver Region (1756-1770). It is necessary to give special attention to the analysis of the decoration of this monument, because it is a vivid example of provincial church of the volumetric-spatial composition, that is the object of our research. The corners of the two-tiered cube, the faceted apse, the refectory, and the octagon of the church are decorated with flat double pilasters. Windows of the lower tier of the cube, the altar, and the refectory are decorated in the 'ornamentation' style. There are columns with 'melons' ('dyn'ka', a convex element of the column's shaft) and completed with 'kokoshniks'. Windows of the second tier of the cube, located on three façades, are decorated with developed Baroque platbands. In the decoration of windows of the octagon masters returns to the Old Russian 'ornamented' platbands. Such combination of 'ornamentation' and Baroque is observed even on the level of the decoration of the domes: the central dome has a faceted shape; it is decorated with Baroque platbands with figured panels under them, and pilasters with small volutes; and the side domes are round and decorated with arcature. Such variant can serve as "a clear example of the search for original paths in architecture within the framework of traditions" [16]. The five-domed church of Rogozha is extremely ornamented. In the interior, as in almost all the churches of the same type, the octagon is covered with a solid eight-sided vault; and the transition from the cube to the octagon is carried out through trumpets in the corners ("Figure $5 ")$. 


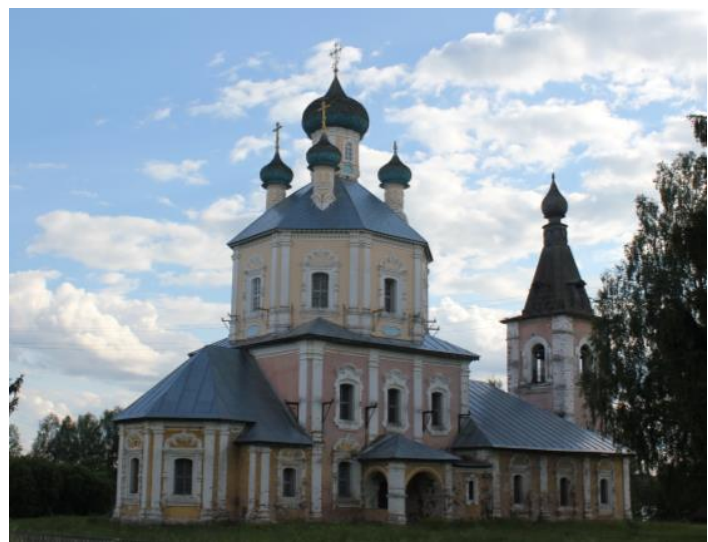

Figure 5 The Church of the Transfiguration of Our Savior in the village of Rogozha. 1756-1770. Author's photo. 2014.

Monuments of the Tver Region demonstrated an obvious interest of masters and customers to the composition of 'five-domed octagon-on-cube', that has been preserved for a long time. For instance, two monastic cathedrals of Ostashkov - in the Znamensky (1732-1742) and Zhitensky (17371742) Cloisters, which originally had a tiered shape crowned with one dome, later got the 'Ukrainian' five-domed head; and the Church of St. Elias in Selikhovo, Konakovsky District (1815-1831), built in the Classicist period, was originally crowned with five domes oriented in the 'Moscow way' [17].

Several monuments of the same volumetricspatial composition are located on the territory of the modern Ivanovo Region: the Resurrection Church in the village of Pistsovo, Komsomolsk District (1748) with 'Naryshkinsky style' window platbands and double 'kokoshniks' at the top of each side of the octagon [18]; the Holy Trinity Church in the village of Kholui, Yuzhsky District (1748-1750) with similar double 'kokoshniks' and semicircular windows [19]; the Church of the Holy Trinity in the village of Maryinskoe, Furmanovsky District (1778) [20] with its modest archaic decoration; the Church of the Holy Trinity in the village of SpasShelutino, Palekh District (1797) the architecture of which combines Baroque and Classicist features [21]. The Church of the Assumption of the Assumption Monastery in Dunilov, Shuisky District (1819), was built completely in the Classicist style; and its octagon was turned into a rotunda [22].

The replacement of octagon with rotunda in the 'octagon-on-cube' type can be noted in other monuments of the late eighteenth - early nineteenth centuries built in the Classicist style. The examples can be found in the Church of the Nativity of Christ in the village of Arefino, Rybinsk District, Yaroslavl Region (1789) [23], and the Church of the Resurrection of Christ in the village of Parfenievo, Parfenievsky District of the Kostroma Region (1790) [24].

Our survey includes mainly the monuments of stone architecture. We will only mention the fact that the volumetric-spatial composition of 'fivedomed octagon-on-cube' is found in wooden architecture, as well: in particular, in those churches that directly repeat the forms of stone architecture. An example is the Church of the Kazan Icon of Theotokos in the village of Veliky Vrague, Kstovsky District of the Nizhny Novgorod Region with the diagonal setting of its domes (1792) [25]. We should note, that the crowning part of tiered wooden churches with five domes oriented to the cardinal points were generally widespread in wooden architecture; it can be observed on the example of monuments of Nizhny Novgorod, among which there are now lost churches of the Vetluzhsky District - that one of St. Charalambos in the village of Belyshev (1751) and the Church of Archangel Michael of the village of Arkhangelskoe-on-Vol (Volyntsy) (1755) [26].

The two monuments of the Nizhny Novgorod Region are a rare example of five-domed stone architecture oriented to the cardinal points, built as 'octagon-on-cube', not typical for the stone architecture of the Modern Time. In the period of Late Classicism, the Transfiguration churches were built in the villages of Sitskoe (1831) and Vershilovo (1835) [27], both on the territory of the Chkalovsky District. The 'Ukrainian' five-domed type of these churches, obviously, was chosen under the influence of the forms of the Stroganov Church in Nizhny Novgorod.

This survey of churches of the 'octagon-oncube' type crowned with five domes is quite short and far from comprehensive list of monuments; it testifies the great importance of preserving the fivedomed heads of churches in the context of changing stylistic fashion. The type of 'octagon-on-cube', appeared in the epoch of Peter the Great, has been in demand for a long time. At the same time, many churches were crowned with traditional type of five domes, popular in the late Middle Ages and still in demand in the Modern Time.

Once again, we draw attention to the fact that some churches built with one dome in the first quarter of the eighteenth century, were rebuilt in the end of the same century, getting five domes. An 
example is the Church of the Resurrection on Pushhavka in the village of Puchezh, Ivanovo Region, which has not survived till nowadays; it was built thanks the efforts by Metropolitan Job of Novgorod and Galich in 1717. The church was a provincial example of the 'octagon-on-cube', decorated with a mixture of the 'ornamentation' and 'Naryshkinsky' styles. In the inventory of 1764, it is mentioned as one-domed; and in 1803, documents mention its five dome [28]. The monument with five domes was fixed in photographs in the early twentieth century; the photo made before its demolishing in early 1950 s is preserved in the Yurievets Museum of History and Art. In the photo we see that the two-tiered cube was flanked with enveloping lesenes; along its top there was a zigzag frieze. The corners of the octagon were decorated with columns on lesenes; and the edges had an unusual flooted decoration. In the upper part of the octagon there was a frieze with a wavy 'kokoshnik' on each side. Windows were completed with 'kokoshniks' and broken platbands. A three-partite altar was located from the east side. The octagon was crowned with five domes on faceted drums decorated with Baroque elements. ("Figure 6")

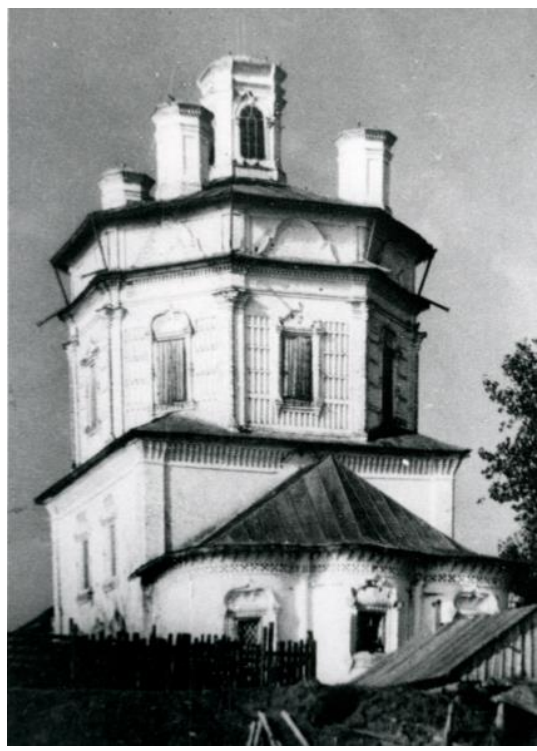

Figure 6 The Church of the Resurrection on Pushhavka in Puchezh. 1717; rebuilt in the late eighteenth century. Photo made before the demolishing. Early 1950s.

\section{CONCLUSION}

The publication considered the issue of typology of churches built as 'octagon-on-cube' in the period of the 'Naryshkinsky style'; it combined that new structure with traditional five-domed heads and existed in such combination in provincial architecture through the eighteenth and nineteenth centuries. A more detailed analysis of two monuments - the church in the village of Rogozha and the lost church in Puchezh - allows us to trace the mechanisms of shaping architectural images. In the first case, there is a one-time built five-domed church of the 'octagon-on-cube' type, the decoration of which mixed elements of Old Russian 'ornamentation' and Baroque. In the second case, a single-domed church of the same type with a combined decoration of the 'ornamentation' and 'Naryshkinsky' styles was upgraded to five domes during the reconstruction in the late eighteenth century.

Some monuments were constructed as two octagons on the cube; it allowed masters to get more height of buildings. In the epoch of Classicism, octagon gave place to rotunda. That new architectural composition was shaped at the transition period between the Middle Ages and the Modern Time and passed through all stylistic transformations up to the Late Classicism; it testifies an exclusive importance of keeping traditional schemes. The current research is embedded in a whole cycle of similar studies and observations on certain architectural variants, particularly, three-partite volumetric-spatial compositions [29] and tetraconch churches [30] in the late seventeenth century and further on.

The problem of studying tradition and innovation in Russian architecture has long been the focal point of our research. In particular, the question of different versions of the five-domed churches in Russian architecture of the late seventeenth - early eighteenth centuries was raised in the work "On the Fate of a Variant of the Fivedomed Building in the Russian Architecture of Peter the Great's Time" [31]. A number of articles were published on the phenomenon of preservation of the type of a traditional pillarless church in the transition period. The main conclusions on the topic were published in the Ph.D. thesis "Traditional Pillarless Churches of the Naryshkinsky style" [32]. Problems of preserving the medieval typological scheme during the eighteenth and nineteenth centuries were also considered by us, on the example of the spread of the double-column structure, in the article "Double-column Churches of the Yaroslavl Region: on the Development of the Type in the Upper Volga Rregion in the Seventeenth - Eighteenth Centuries" [33]. A special article was on the genesis of the type of monastery church-belfry over the gates and its further spread 
in the architecture of the Modern Time [34]. The current reflections continue the topic of studying the phenomenon of preserving traditional compositions in the Russian architecture of the eighteenth and nineteenth centuries and the creative potential of provincial masters who used certain elements of large styles and combined them with traditional well-known schemes. The easily recognizable traditional five-domed structure was combined with completely different types, in this case, with a composition of 'octagon-on-cube', that seems not very suitable in terms of volumetric solution, and, despite the change in styles, for a long time it has remained in the sphere of attention of provincial architects and customers of local churches.

\section{AUTHORS' CONTRIBUTIONS}

This paper is independently completed by Natalia Merzlyutina.

\section{REFERENCES}

[1] M. Kaverznev, P. Maksimov. The Church of the Rozhdestvensky Pogost on the Pakhra River (Tserkov Rozhdestvenskogo pogosta na reke Pakhre) // Architectural Heritage (Architekturnoe nasledstvo), Iss. 10. 1958, pp. 173-178 [In Russian].

[2] Sorok sorokov (Sorok sorokov). V. 2. Moscow: Kniga i bisness, Krom, 1994, Iss. 70, pp. 263-267 [In Russian].

[3] Sorok sorokov. (Sorok sorokov). V. 2. Moscow: Kniga i bisness, Krom, 1994, Iss. 53, pp. 226-230 [In Russian].

[4] O.I. Braytseva. Stroganov Vuildings of the Turn of the 17th -18th Centuries (Stroganovskie postroiki rubezha XVII-XVIII vekov). Moscow: Stroyisdat, 1977, pp. 73-106 [In Russian].

[5] Sorok sorokov (Sorok sorokov). V. 2. Moscow: Kniga i bisness, Krom, 1994, Iss. 58, pp. 236-237 [In Russian].

[6] M.N. Karger. Novgorod. Moscow: Iskusstvo, 1980, pp. 221-223 [In Russian].

[7] E. Dobrovolskaya. Yaroslavl. Moscow: Iskusstvo, 1968, pp. 177-186 [In Russian].

[8] L.K. Maciel Sanches. Architectural Development of Siberia in the early 18th Century (Architecturnoe osvoenie Sibiri v nachale 18 v. // Architectural Heritage (Architekturnoe nasledstvo). Iss. 60. Moscow - St. Petersburg: Kolo, 2014, pp. 144-160 [In Russian].

[9] L.K. Maciel Sanches. Architectural Development of Siberia... (Architectural development of Siberia...), pp. 154-156[In Russian].

[10] Architectural Monuments of the Kostroma Region (Pamyatniki architecturi Kostromskoi oblasti).V. 11. Nerechta and Nerechtsky district (Nerechta i Nerechtsky raion). Kostroma, Committee for the Protection and Use of Historical and Cultural Heritage (Komitet po ohrane i ispolsovaniu istorikokulturnogo nasledia), 2009, pp. 140-141[In Russian].

[11] Brief Statistical Information about Parish Churches of the Kostroma Diocese. Reference book (Kratkie statisticheskie svedenia o prihodskih cerkvah Kostromskoi eparhii. Spravochnaya kniga), Kostroma, Provincial printing house (Gubernskaya tipographia),1911, pp. 16-17 [In Russian].

[12] Architectural Monuments of the Kostroma Region. (Pamyatniki architecturi Kostromskoi oblasti). V. IV. Soligalich and the Soligalich District (Soligalich i Soligalichsky raion), Kostroma, Committee for the Protection and Use of Historical and Cultural Heritage (Komitet po ohrane i ispolsovaniu istorikokulturnogo nasledia), 2002, pp. 145-147 [In Russian].

[13] Architectural Monuments of the Kostroma Region (Pamyatniki architecturi Kostromskoi oblasti).V. IV. Soligalich and the Soligalich District (Soligalich i Soligalichsky raion), Kostroma, Committee for the Protection and Use of Historical and Cultural Heritage (Komitet po ohrane i ispolsovaniu istorikokulturnogo nasledia), 2002, pp. 242-243 [In Russian].

[14] The Catalogue of Monuments of Architecture and Monumental Art of Russia. Smolensk Region, (Svod pamyatnikov architecture i monumentalnogo iskysstva Rossii. Smolenskaya oblast). Moscow: Nauka, 2001, pp. 375-376 [In Russian]. 
[15] The Catalogue of Monuments... Smolensk Region... (Svod pamyatnikov... Smolensk region...), p. 18 [In Russian].

[16] A. A. Galashevich. Artistic Monuments of the Seliger Region (Hudozhestvennie pamyatniki Seligerskogo kraya). Moscow: Iskusstvo, 1983, pp. 73-76 [In Russian].

[17] The Catalogue of Monuments of Architecture and Monumental Art of Russia. Tver Region (Svod pamyatnikov architecture i monumentalnogo iskysstva Rossii. Tverskaya oblast). V. 1. Moscow: Nauka, 2003. pp. 4445; 101 [In Russian].

[18] The Catalogue of Monuments of Architecture and Monumental Art of Russia. Ivanovo Region (Svod pamyatnikov architecture i monumentalnogo iskysstva Rossii. Ivanovskaya oblast). V. 2, Moscow: Nauka, 2000, 534-537 [In Russian].

[19] The Catalogue of Monuments of Architecture and Monumental Art of Russia. Ivanovo Region (Svod pamyatnikov architecture i monumentalnogo iskysstva Rossii. Ivanovskaya oblast). V. 3, Moscow: Nauka, 2000, pp. 692-696 [In Russian].

[20] The Catalogue of Monuments of Architecture and Monumental Art of Russia. Ivanovo Region (Svod pamyatnikov architecture i monumentalnogo iskysstva Rossii. Ivanovskaya oblast). V. 3, Moscow: Nauka, 2000, pp. 347-349 [In Russian].

[21] The Catalogue of Monuments of Architecture and Monumental Art of Russia. Ivanovo Region (Svod pamyatnikov architecture i monumentalnogo iskysstva Rossii. Ivanovskaya oblast). V. 2, Moscow: Nauka, 2000, pp. 705-707 [In Russian].

[22] The Catalogue of Monuments of Architecture and Monumental Art of Russia. Ivanovo Region (Svod pamyatnikov architecture i monumentalnogo iskysstva Rossii. Ivanovskaya oblast). V. 3, Moscow: Nauka, 2000, pp. 595-598 [In Russian].

[23] N.S. Borisov, N.S. Marasinova. Rybinsk Myshkin - Poshekhonye, Moscow: Astrel, 2007, pp. 181-186 [In Russian].

[24] Architectural Monuments of the Kostroma Region (Pamyatniki architecturi Kostromskoi oblasti). V. IX. Antropovsky District,
Parfenievsky District, Ostrovsky District, Sudislavsky District (Antropovsky raion, Parfenyevsky raion, Ostrovsky raion, Sudislavsky raion), Committee for the Protection and Use of Historical and Cultural Heritage (Komitet po ohrane $\mathrm{i}$ ispolsovaniu istoriko-kulturnogo nasledia), Kostroma, 2007 pp. 93-97 [In Russian].

[25] Historical and Cultural Monuments of the Gorky Region (Pamyatniki istorii I kyltyri Gorkovskoi oblasti). Gorky: Volgo-Vyatskoe knizhnoe izdatelstvo, 1980, p. 199 [In Russian].

[26] Proceedings of the Imperial Archaeological Commission (Isvestiya Imperatorskoi argeologicheskoi komissii). V. 31. (Restoration issues (Voprosi restavracii). V. VIII). S.-Peterburg, 1909, Iss. 193, p. 141, f. 66; Iss. 196, p. 144; f. 71 [In Russian].

[27] Historical and Cultural Monuments of the Gorky Region (Pamyatniki istorii I kyltyri Gorkovskoi oblasti). Gorky: Volgo-Vyatskoe knizhnoe izdatelstvo), 1980, p . 211[In Russian].

[28] N.N. Rozhdestvensky. Voskresensky Pushavin Monastery and the Voskresenskaya Church of Puchezh (Voskresensky Pushavin Monastir i Voskresenskaya cerkov Puchezha), Puchezh, 1932. Archive of the Puchezhsky Museum [In Russian].

[29] A.V. Chekmarev. Two-towered Churches of Slobozhanshchina: Transformation of the Ukrainian Typology in the 18th - early 19th Centuries (Dvybashennie hrami Slobozhanshchini: transformaciya ukrainskoi tipologii v XVIII - nachale XIX vv. // Russian Manor. Collection of the Society for the Study of the Russian Estate (Rysskaya usadba. Sbornik obshchestva izucheniya rysskoi usadbi). V. 18 (34). St. Petersburg: Kolo, 2013, pp. 277-311[In Russian].

[30] A. N. Yakovlev. Typology of Tetraconchs in the Russian Church Architecture of the Baroque Era (Tipologia tetrakonchov $\mathrm{V}$ russkoi cerkovnoi architecture epochi barokko // Actual problems of the theory and history of art: collection of scientific articles (Aktualnie problem teorii $\mathrm{i}$ istorii isrusstva). Iss. $10 /$ Edited by A. V. Zaharova, S. V. Maltseva, E. J. Stanukovich-Denisova. Moscow State 
University / St. Petersburg: NP-Print, 2020, pp. 182-196. DOI: http://dx.doi.org/10.18688/aa200-2-17 [In Russian].

[31] N. A. Merzlyutina. On the Fate of a Variant of the Five-domed Building in the Russian architecture of Peter the Great's Time (O sydbe odnogo variant pyatiglavia $\mathrm{v}$ rysskoi architecture Petrovskogo vremeni) // Peter the Great and His Time (Peter Veliky i ego vremya). Materials of the All-Russian Scientific Conference dedicated to the 290th anniversary of the Battle of Poltava on July 811, 1999. St. Petersburg, 1999, pp. 88-91[In Russian].

[32] N.A. Merzlyutina. Traditional Pillarless Churches of the 'Naryshkinsky Style' (Tradicionnie besstolpnie hrami narishkinskogo stilya). Moscow, 2002, 26 pp [In Russian].

[33] N. A. Merzlyutina. Double-column Churches of the Yaroslavl Region: on the Development of the Type in the Upper Volga Region in the 17th - 18th Centuries (Dvystolpnie cerkvi Yaroslavskoi oblasti: k voprosy o razvitii tipa v Verchnem Povolzhie v XVII-XVIII vekach // Architectural Heritage (Architecturnoe nasledstvo). Iss. 69. St. Petersburg: Kolo, 2018, pp. 18-30 [In Russian].

[34] Natalia Merzlyutina. The Gate Belfry of Vysokopetrovsky Monastery with the Church of the Intercession: to the Question of the Genesis of the Type // The 2nd International Conference on Architecture: Heritage, Traditions and Innovations (AHTI 2020). DOI:

https://doi.org/10.2991/assehr.k.200923.025. 